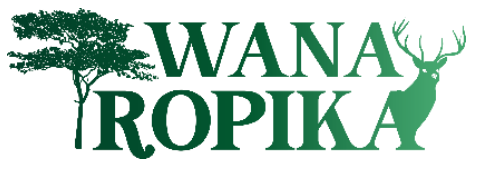

Journal Wanatropika. Vol. 11, No. 2 November 2021

Journal home page: https://jurnal.instiperjogja.ac.id/index.php/JWT/

ISSN: 2088-7019

\title{
DAUR VOLUME OPTIMAL JATI DI HUTAN RAKYAT (STUDI KASUS DI DESA GIRIKARTO, KECAMATAN PANGGANG, KABUPATEN GUNUNG KIDUL)
}

\author{
Rotation of Optimum Volume Production in Teak Private Forest (Case Study in Girikarto \\ Village, Panggang Sub District, Gunung Kidul District)
}

\section{Tatik Suhartati $^{1}$, Pebriansyah ${ }^{1}$}

${ }^{1}$ Fakultas Kehutanan Institut Pertanian Stiper Yogyakarta, Korespondensi Penulis: wanatropikajurnal@gmail.com

\begin{abstract}
The aim of this research is to define rotation of optimal volume production of teak private smallholder forest. Sample of trees were taken by using purposive sampling method in cutting activity area. Seventy trees have choosen by diameter distribution, healthy and straigh stem. Every sample trees were measured with stem analysis method. Rotation of maximum volume production define by growth curve, mean annual increament (MAI) and current annual increament (CAI) curve. The result show that height youth stage begin 2 until 6 year, diameter youth stage begin 3 until 10 year, volume youth stage begin 4 until 25 year and rotation of maximum volume production is 25 year.
\end{abstract}

Key words: Rotation of optimal volume production, Stem analysis, Growth curve

\section{PENDAHULUAN}

Pengelolaan hutan di Indonesia saat ini dihadapkan pada permasalahan ketidakseimbangan pasokan kayu dengan kapasitas industri. Oleh karena itu selalu terjadi kekurangan bahan baku kayu. Produksi kayu bulat dari hutan rakyat disambut baik oleh pelaku industri perkayuan seiring dengan laju deforestasi netto yang pada periode 2016-2017 mencapai 0,48 juta hektar per tahun (KLHK, 2018). Laju deforestasi ini membuat suplai kayu dari hutan negara semakin tidak dapat mencukupi. Keberadaan hutan rakyat telah terbukti memberikan kontribusi besar terhadap pasokan bahan baku industri kayu seperti industri mebel, industri pengergajian dan industri kerajinan bahkan kini industri kayu lapis pun telah mulai menggantungkan bahan bakunya pada hutan rakyat. Menurut Saputra (2012) sejumlah 
perusahaan besar kayu lapis yang semula menguasai ribuan hektar hutan di Kalimantan dan Sumatera mulai memindahkan pabriknya ke Jawa.

Tebangan kayu di hutan rakyat menunjukkan bahwa terdapat banyak variasi umur tebang, khususnya pada pengusahaan hutan rakyat jati di Gunung Kidul. Secara umum daur yang dikenal di hutan rakyat adalah daur butuh, karena kayu ditebang sesuai dengan waktu kapan membutuhkan uang. Oleh karena itu penelitian ini ingin menemukan apakah daur butuh rata-rata pada pengusahaan jati di hutan rakyat sudah mendekati daur volume optimal yang sesuai dengan pertumbuhan jati di wilayah penelitian.

Salah satu cara mempelajari pertumbuhan adalah melalui metode analisis batang. Metode analisis batang dilakukan dengan jalan menganalisis jumlah dan panjang jari-jari lingkaran tahun pada batang pohon jati. Waktu yang diperlukan untuk memperoleh data relatif cepat dan data yang dihasilkan lebih akurat (Huch et al., 1982). Menurut Perez (2008), analisis batang telah terbukti menjadi alat yang berguna untuk membuat database pertumbuhan jika tidak ada pengukuran berurutan (time-series) atau untuk mendukung database sejarah pertumbuhan yang ada.

Analisis batang dapat menghasilkan gambaran kurva pertumbuhan. Menurut Husch et al. (1982) kurva pertumbuhan pohon merupakan penggambaran ukuran atau dimensi pertambahan suatu pohon (tinggi, diameter, volume) diatas umur, kurvanya berbentuk sigmoid yang menggambarkan ukuran hasil pertumbuhan komulatif pada umur pertumbuhannya. Bentuk umum kurva pertumbuhan komulatif tumbuh-tumbuhan yang berbentuk sigmoid tersebut akan memiliki tiga tahap, yaitu tahap pertumbuhan eksponensial, tahap pertumbuhan mendekati linear dan pertumbuhan asimptotis (Davis dan Johnson, 1987).

Berapa cepat titik pertumbuhan pohon berubah disebut dengan kecepatan pertumbuhan, dengan kata lain merupakan perubahan dimensi (tinggi, diameter, volume) pertumbuhan setiap selang waktu. Dikenal dua pengertian yaitu kecepatan sesaat dan kecepatan rata-rata untuk menyatakan kecepatan pertumbuhan atau laju titik pertumbuhan. Pengukuran besarnya kecepatan sesaat dinamakan Current Annual Increament (CAI), sedangkan kecepatan pertumbuhan rata-rata dinamakan Mean Annual Increament (MAI) (Husch et al., 1982).

Dengan demikian menganalisis pertumbuhan dengan menggunakan metode analisis batang ini dapat mengetahui kecepatan tumbuh tahunan rata-rata (MAI) dan kecepatan tumbuh tahunan berjalan (CAI). Mindawati et al. (2010) menyebut pertemuan kurva CAI dan MAI merupakan daur volume optimal suatu pohon untuk ditebang. Daur optimal tegakan dilihat dari riap pertumbuhan maksimal yang ditentukan berdasarkan telah adanya titik potong antara kurva riap tahunan berjalan. Menurut Suhartati (1993), jika telah tercapai daur volume optimal 
tetapi pohon belum ditebang, maka tambahan hasil volume yang akan diperoleh sangat kecil dibanding waktu yang diperlukan untuk tumbuh. Sebaliknya jika menebang pohon sebelum umur daur, hasil kayu maksimum juga kurang tepat karena pohon masih dalam masa pertumbuhan relatif cepat. Oleh karena itu pengelola hutan rakyat perlu memperoleh gambaran mengenai daur volume optimal, agar dapat memperoleh volume kayu secara maksimal.

\section{BAHAN DAN METODE}

Data diambil dari pohon-pohon hasil tebangan di Desa Girikarto, Kecamatan Panggang, Kabupaten Gunung Kidul, Propinsi Yogyakarta. Alat-alat yang digunakan dalam penelitian ini antara lain loupe (kaca pembesar 5 kali perbesaran), pita ukur dan penggaris.

Pohon yang diambil sebagai sampel adalah pohon jati yang ada di hutan rakyat di Desa Girikarto. Sebanyak 60 pohon dipilih secara purposive berdasarkan variasi diameter, kesehatan dan kelurusan batang. Setiap sampel pohon yang telah ditebang selanjutnya dilakukan pengukuran dengan prosedur analisis batang. Langkah-langkah analisis batang mengikuti Huch et al. (1982).

Tinggi pohon diperoleh dengan cara mengukur dan mencatat tinggi tunggak serta panjang masing-masing seksi sampai ujung pohon. Sedangkan umur pohon diperoleh dari hasil mengukur dan menghitung jumlah lingkaran tahun setiap ujung seksi. Diameter pohon diperoleh dari mengukur diameter setiap ujung seksi. Umur pohon dihitung dari jari-jari setiap 5 lingkaran tahun dari titik tengah batang keluar.

Hubungan antara tinggi atau diameter dan umur dinyatakan dalam persamaan model growth. Model ini berbentuk sigmoid (Pratisto, 2009) yaitu:

$$
\mathrm{Y}=\mathrm{e}^{\mathrm{a}+\mathrm{b} / \mathrm{X}}
$$

Dimana: $\mathrm{Y}=$ Tinggi atau diameter pohon; $\mathrm{e}=$ Bilangan alam=2,714; $\mathrm{a}=$ Kostanta;

$$
\mathrm{b}=\text { Koefisien regresi; } \mathrm{X}=\mathrm{Umur}
$$

Selanjutnya dari persamaan dilakukan perhitungan CAI dan MAI:

$$
\begin{gathered}
\mathrm{CAI}_{\mathrm{H}}=\frac{H_{t}-\left(H_{t-1}\right)}{t-\left(t_{-1}\right)} \text { dan } \mathrm{CAI}_{\mathrm{D}}=\frac{D_{t}-\left(D_{t-1}\right)}{t-\left(t_{-1}\right)} \\
\mathrm{MAI}_{\mathrm{H}}=\frac{H_{t}}{t} \mathrm{~m}^{3} / \text { th dan MAI } \mathrm{D}=\frac{D_{t}}{t}
\end{gathered}
$$

Dimana: H: Tinggi pohon; D: Diameter setinggi dada; Ht: Tinggi pohon pada umur t;

Dt: Diameter pohon pada umr t; t: Umur pohon; Ht-1: Tinggi pohon pada tahun sebelumnya 
Volume batang dihitung menggunakan rumus umum (Simon, 1996):

$$
\mathrm{V}=\frac{1}{4} \Pi \cdot \mathrm{d}^{2} \mathrm{~h} \cdot \mathrm{f}
$$

Dimana: $\mathrm{d}=$ diameter; $\mathrm{h}=$ tinggi; $\mathrm{f}=$ bilangan bentuk; $\Pi=3,14$

Tinggi dan diameter pohon untuk menghitung volume menggunakan hasil prediksi pada fungsi pertumbuhan tinggi maupun diameter. Rumus perhitungan bilangan bentuk sebagai berikut:

$$
\mathrm{f}=\frac{V b}{V s}
$$

Dimana: f: Bilangan bentuk absolut; Vb: Volume batang ; Vs: Volume silinder

Perhitungan Current Annual Increment (CAI) dan Mean Annual Increment (MAI) dihitung dengan rumus yang sama dengan pada perhitungan CAI dan MAI tinggi dan diameter pohon.

\section{HASIL DAN PEMBAHASAN}

Desa Girikarto merupakan daerah yang mempunyai topografi berbukit dengan kemiringan yang terjal di beberapa tempat dengan menyisakan beberapa tempat yang relatif datar. Menurut monografi Desa Girikarto, secara vertikal desa Girikarto terletak pada ketinggian 200-250 meter di atas permukaan laut. Jenis tanah yang ditemui terdiri dari komplek Litosol dan Mediteran Merah dengan bahan induk batuan kapur, bentuk wilayah bergelombang sampai berbukit. Tipe iklim agak basah atau tipe zone $\mathrm{C}$ dimana terdapat 4-6 bulan basah. Desa Girikarto memiliki suhu udara rata-rata $28^{\circ}-34^{\circ} \mathrm{C}$ dan memiliki curah hujan rata-rata sebesar $2.500 \mathrm{~mm} / \mathrm{th}$.

Hutan rakyat yang terdapat di Desa Girikarto sebagian besar ditanami tanaman keras dengan dominasi Jati dan campuran Akasia, Mahoni, dan tanaman buah-buahan seperti Mangga, Rambutan, Pete, Durian, dan sebagainya. Masyarakat memanfaatkan lahan yang kurang subur dengan menanam jenis tanaman keras dan tanaman perkebunan. Jika pada musim hujan lahan dimanfaatkan oleh masyarakat untuk tanaman pertanian seperti tanaman Jagung, Kedelai, Kacang tanah, Ketela.

Sistem tebangan hutan rakyat menggunakan sistem tebang butuh artinya pohon akan ditebang tanpa memperhatikan umur atau ditebang sesuai waktu dibutuhkan uang. Penebangan pohon tidak memperhatikan daur, jadi dapat terjadi menebang di atas maupun di bawah umur daur volume optimalnya. Padahal jika pohon masih dalam masa pertumbuhan maka menebang pohon berarti menghilangkan kesempatan memperoleh volume yang lebih besar. Informasi 
pertumbuhan jati dapat diperoleh antara lain dari hasil merekontruksi pertumbuhan pohon dengan mengunakan lingkaran tahun. Hasil dari informasi ini diharapkan dapat membantu masyarakat dalam proses pemeliharaan dan pemanenan kayu, sehingga petani tahu kapan waktu yang pas menjual hasil kayunya dan waktu memelihara tegakan, dengan demikian pendapatan masyarakat dari hutan rakyat dapat meningkat.

Hubungan yang mengekspresikan pertumbuhan tinggi dan diameter pohon sebagai fungsi umur dapat di nyatakan dalam persamaan regresi. Persamaan yang digunakan adalah fungsi growth yang berbentuk sigmoid. Hasil analisis regresi pertumbuhan komulatif tinggi dan diameter pohon disajikan dalam Tabel 1. Selanjutnya dilakukan prediksi tinggi dan diameter pohon pada berbagai umur berdasarkan persamaan regresi yang diperoleh. Kurva hasil prediksi pertumbuhan tinggi dan diameter pohon dapat dilihat pada Gambar 1 dan Gambar 2.

Tabel 1. Hasil Analisis Regresi Tinggi dan Diameter Pohon

\begin{tabular}{|c|c|c|c|c|}
\hline Variabel & B & $\begin{array}{c}\text { Standar error } \\
\text { Tinggi }\end{array}$ & T hitung & Taraf signifikan \\
\hline $1 /$ umur & $-5,427$ & 0,053 & $-103,289$ & $0,000 * *$ \\
\hline Konstanta & 2,789 & 0,022 & 125,502 & $0,000 * *$ \\
\hline Koefisien determinasi $\left(\mathrm{R}^{2}\right)$ & & & & \\
\hline \multicolumn{5}{|l|}{ Standar error regresi } \\
\hline \multicolumn{5}{|c|}{ DIAMETER SETINGGI DADA } \\
\hline $1 /$ umur & $-9,971$ & 0,258 & $-38,708$ & $0,000 * *$ \\
\hline Konstanta & 3.615 & 0,032 & 111,62 & $0,000 * *$ \\
\hline Koefisien determinasi $\left(\mathrm{R}^{2}\right)$ & & & & \\
\hline Standar error regresi & & & & \\
\hline
\end{tabular}

Keterangan: ** Signifikan pada taraf uji 0,01

Kurva pada Gambar 1 menggambarkan kecepatan pertumbuhan tinggi mencapai titik maksimal pada umur 3 tahun yaitu sebesar 1, $5860 \mathrm{~m} / \mathrm{th}$. Mean Annual Increment (MAI) atau riap tahunan rata-rata didapat dari hasil pembagian antara tinggi pohon umur tertentu $\left(\mathrm{H}_{\mathrm{t}}\right)$ dengan umur pohon $(\mathrm{t})$, Kecepatan pertumbuhan rata-rata mencapai puncak pada umur 5 tahun dengan kecepatan rata-rata pertumbuhan sebesar 1,0987 m/th. Pertumbuhan tinggi mencapai hasil maksimum pada saat grafik CAI dan MAI bertemu di suatu titik dalam suatu gerakan pertumbuhan. Pertemuan grafik CAI dan MAI terjadi pada jati mendekati umur 6 tahun dengan tinggi maksimal yaitu 6,6 meter. Riap CAI sebesar 1,0893 m/th sedangkan untuk MAI yaitu sebesar $1,0971 \mathrm{~m} / \mathrm{th}$. 


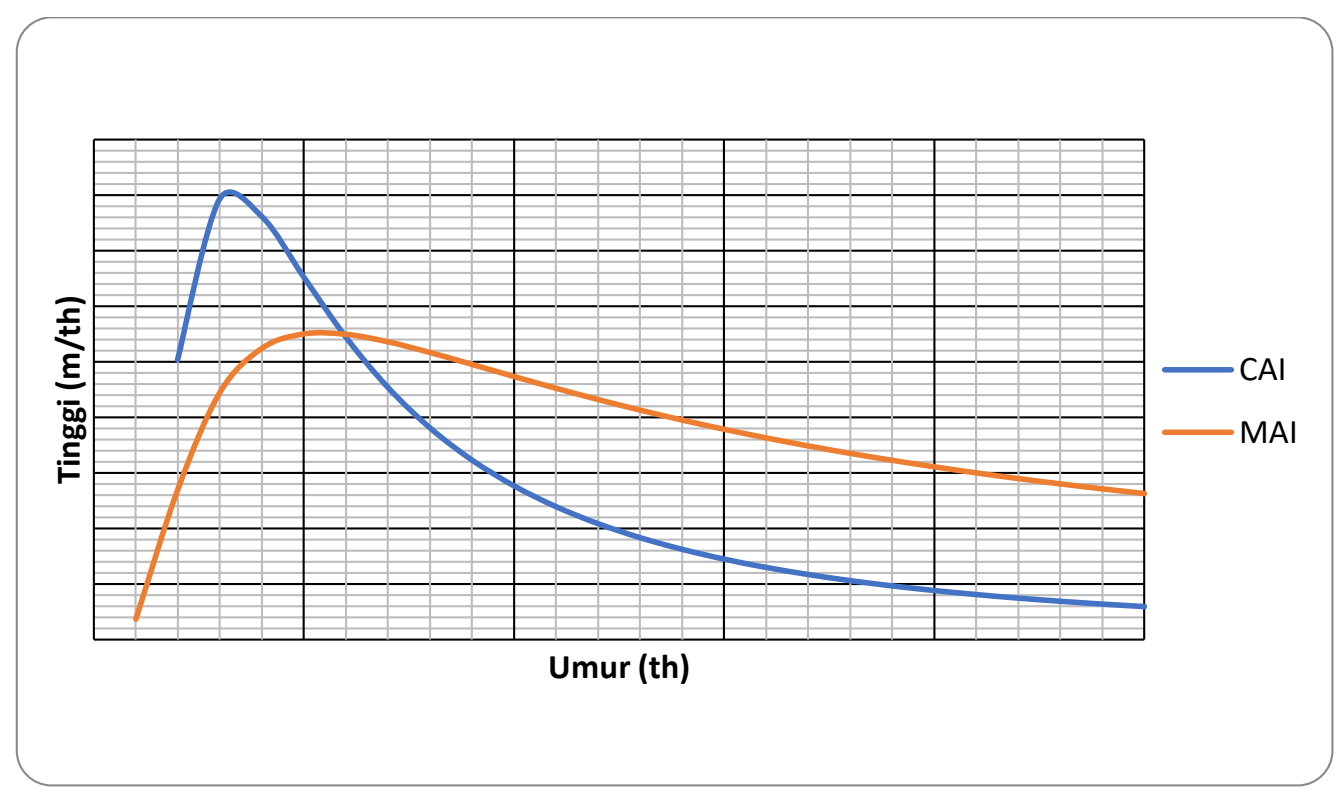

Gambar 1. CAI-MAI Tinggi

Gambar 2 menunjukkan bahwa kecepatan pertumbuhan diameter mencapai titik maksimal pada umur 6 tahun yaitu sebesar 2,0026 cm/th. Kecepatan pertumbuhan rata-rata mencapai puncak pada umur 10 tahun, yaitu sebesar $1,3781 \mathrm{~cm} /$ th. Pertemuan grafik CAI dan MAI terjadi pada jati mendekati umur 11 tahun dengan diameter $15 \mathrm{~cm}$, CAI sebesar 1,3001 $\mathrm{cm}$, dan MAI sebesar $1,3710 \mathrm{~cm} / \mathrm{th}$. Penelitian Lukmandaru et al. (2010) mendapatkan riap tahunan jati di Kecamatan Panggang berkirat antara $1,1 \mathrm{~cm} /$ th sampai dengan 2,0 cm/th.

Pertumbuhan diameter pohon merupakan salah satu faktor penting untuk meningkatkan produktivitas hutan terutama kayu. Peningkatan diameter akan sangat berpengaruh besar terhadap penambahan volume pohon. Riap diameter sangat dipengaruhi oleh jarak tanam dan ruang tumbuh. Pertumbuhan diameter pada hutan rakyat di Girikarto tidak terlalu maksimal, walaupun demikian hal ini bukan semata disebabkan oleh jarak tanam akan tetapi diduga karena petani relatif tidak melakukan pemeliharaan secara teratur, sehingga riap diameter menjadi terhambat. 


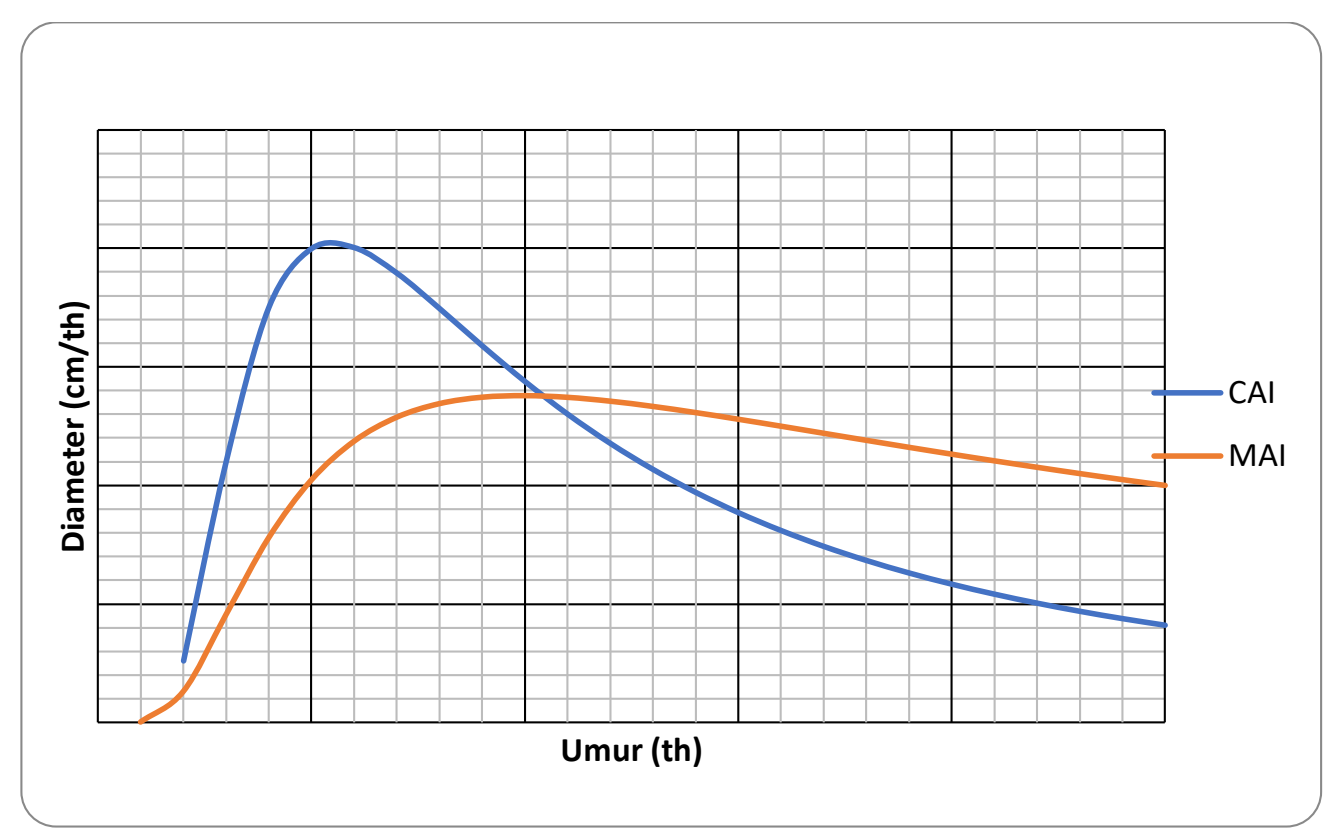

Gambar 2. CAI-MAI Diameter

Petumbuhan volume dihitung menggunakan tinggi dan diameter pohon hasil prediksi dari fungsi pertumbuhan tinggi maupun diameter untuk setiap umur. Bilangan bentuk rata-rata hasil penelitian ini adalah 0,6. Gambar 3 menyajikan CAI-MAI volume pohon dengan umur yang diekstrapolasi hingga 30 tahun.

Kecepatan pertumbuhan volume mencapai titik maksimal pada umur 13 tahun yaitu sebesar $0,0226 \mathrm{~m}^{3} /$ th. Kecepatan pertumbuhan rata-rata mencapai puncak pada umur 25 tahun dengan kecepatan rata-rata pertumbuhan sebesar $0,0153 \mathrm{~m}^{3} /$ th. Pertemuan grafik CAI dan MAI volume jati mendekati umur 26 tahun dengan volume maksimal yaitu $0,4001 \mathrm{~m}^{3}$. Riap CAI sebesar $0,0152 \mathrm{~m}^{3} /$ th sedangkan MAI sebesar $0,0153 \mathrm{~m}^{3} /$ th. 


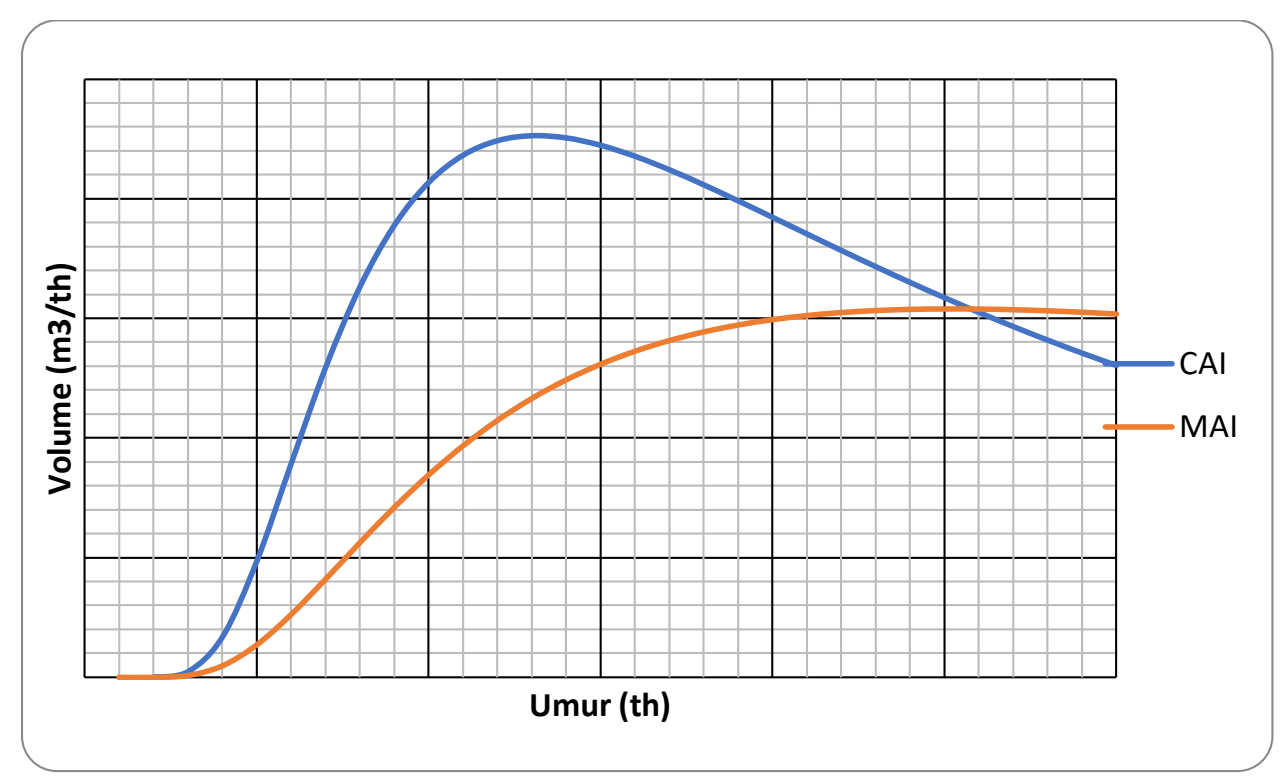

Gambar 3. CAI-MAI Volume

Menurut Simon (1996), riap volume tegakan tergantung pada kepadatan (jumlah) pohon yang menyusun tegakan tersebut (degree of stocking), jenis dan kesuburan tanah. Riap volume suatu pohon dapat dilihat dari kecepatan tumbuh diameter, yang setiap jenis mempunyai laju (rate) yang berbeda-beda. Semua jenis pada waktu muda umumnya mempunyai kecepatan tumbuh diameter yang tinggi, kemudian semakin tua semakin menurun sampai akhirnya berhenti. Pada hutan tanaman biasanya pertumbuhan diameter grafiknya berbentuk huruf S (sigmoid) karena pada mulanya tumbuh agak lambat, kemudian cepat lalu menurun. Lambatnya pertumbuhan diameter pada waktu muda disebabkan tanaman hutan ditanam rapat untuk menghindari percabangan yang berlebihan dan penjarangan yang belum memberi hasil (tending thinnings). Dalam pengelolaan hutan, grafik tersebut mempunyai arti yang penting. Manipulasi perlakuan tegakan melalui penelitian untuk memperoleh riap tegakan maksimal, baik MAI maupun CAI, masih memberi peluang yang besar untuk meningkatkan produksi dari hutan rakyat.

Tahap pertumbuhan volume pohon dalam penelitian ini adalah tahap I dimana MAI besar dari pada nol, atau CAI lebih besar dari MAI, terjadi pada pohon jati yang berumur 4 sampai 25 tahun. Tahap II adalah tahap dimana CAI lebih besar dari nol atau MAI lebih besar dari CAI, terjadi pada jati mulai umur 26 tahun, jika ingin memaksimalkan hasil maka tebangan akhir dapat dilakukan pada tahap II ini. Tahap III dimana nilai CAI lebih kecil dari nol. Tahap ini tidak akan mengutungkan lagi jika dilakukan penambahan umur pohon, karena pertumbuhan volume pohon lebih kecil dari pada pertambahan waktu. Berdasarkan hasil penelitian, tahapan ini belum dapat ditentukan. 
Biasanya masyarakat melakukan penebangan pohon jati pada saat pohon jati mencapai umur 10-25 tahun. Pertumbuhan jati mengalami peningkatan sangat pesat pada umur 1 sampai 10 tahun. Tahapan ini sebaiknya dilakukan kegiatan pemeliharaan secara intensif antara lain kegiatan pemupukan, sehingga memberikan tambahan unsur hara mengingat kondisi lahan yang memang tidak subur, pemangkasan dan penjarangan yang akan memberikan ruang tumbuh yang optimal bagi tegakan. Jika tegakan memperoleh ruang tumbuh dan cahaya matahari yang cukup, maka akan terjadi peningkatan hasil pertumbuhan tegakan yaitu tinggi dan diameter yang sangat berperan dalam peningkatan volume pohon, sehingga riap rata-rata tahunan (MAI) akan meningkat. Jika digambarkan maka kurva MAI akan bergesaer ke atas, sehingga titik potong CAI dan MAI akan berada pada umur yang lebih kecil dari 25 th.

Jika dilihat dari penebangan yang terjadi di lapangan, maka daur butuh yang diterapkan oleh masyarakat memang masih di bawah daur volume optimal. Akan tetapi jika dilihat dari ukuran diameter rata-rata yang ditebang adalah minimal $20 \mathrm{~cm}$, berdasar prediksi pertumbuhan diameter, angka tersebut dicapai pada umur 17 tahun. Sedangkan pemanenan tegakan jati sebaiknya dilakukan pada saat pertumbuhan jati tidak mengalami peningkatan yang pesat yaitu pada umur lebih dari 14 tahun. Jadi daur butuh masih dapat diterima, walaupun sebenarnya belum mencapai daur volume opyimal, tetapi sudah melewati masa pertumbuhan cepat. Apabila pada awal pertumbuhan dilakukan kegiatan pemeliharaan secara intensif, maka pertumbuhan jati mengalami peningkatan sangat pesat sehingga hasil yang didapatkan jauh lebih besar dibandingkan dengan tanpa pemeliharaan pada awal pertumbuhanya.

\section{KESIMPULAN}

1. Kecepatan maksimal pertumbuhan tinggi pohon jati dicapai pada umur 6 tahun dengan kecepatan 1,0893 m/tahun, sehingga fase muda untuk tinggi dimulai dari 2 sampai 6 tahun, fase dewasa dimulai dari 6 tahun.

2. Kecepatan maksimal pertumbuhan diameter pohon jati dicapai pada umur 11 tahun dengan kecepatan 1,3001 cm/tahun, sehingga fase muda untuk diameter dimulai dari 3 sampai10 tahun, fase dewasa dimulai dari 11 tahun.

3. Kecepatan maksimal pertumbuhan volome pohon jati dicapai pada umur 26 tahun dengan kecepatan 0,0152 m3/tahun, sehingga fase muda untuk volume dimulai dari 4 sampai 25 tahun, fase dewasa dimulai dari 26 tahun.

4. Daur volume optimal jati mendekati 25 tahun. 


\section{DAFTAR PUSTAKA}

Davis and Johnson. 1987. Forest Management. Mc Graw Hill. Book Company.

Husch, B., Charles, I. M. and Thomas, W. 1982. Forest Mensuration. John Wiley and Sons. New York.

KLHK. 2018. Status Kehutanan Indonesia. Kementerian Lingkungan Hidup dan Kehutanan Indonesia. KLHK. $181 \mathrm{p}$

Lukmandaru, G., Prasetyo, V. E., Sulistyo, J., \& Marsoem, S. N. 2010. Sifat Pertumbuhan Kayu Jati dari Hutan Rakyat Gunungkidul. Dalam Prosiding Seminar "Hutan Kerakyatan Mengatasi Perubahan Iklim”, Fakultas Kehutanan UGM. Jogjakarta. hlm (pp. 79-86).

Mindawati, N., Indrawan, A., Mansur, I., dan Rusdiana, O. 2010. Kajian Pertumbuhan Tegakan Hybrid Eucalyptus urograndis Di Sumatera Utara Growth of Eucalyptus Urograndis Hybrid in North Sumatera. Jurnal Penelitian Hutan Tanaman, 7(1), 39-50.

Perez, D. 2008. Growth and Volume Equations Developed from Stem Analysis for Tectona grandis in Costa Rica. Journal of Tropical Forest Science, 66-75.

Pratisto, A. 2009. Statistik Menjadi Mudah dengan SPSS 17. PT. Elex Media Komputindo. Jakarta.

Saputra, S.M. 2012. Ketika Sawit Jadi Substitusi Meranti. Bisnis Indonesia. 17 April 2012. hal 12. Jakarta.

Simon, H. 1996. Metode Inventore Hutan. Aditya Media. Yogyakarta.

Suhartati, T. 1993. Studi Pertumbuhan Pinus Pendekatan Model Time Series-Cross Section. Tesis (tidak diterbitkan) Fakultas Kehutanan UGM. Yogyakarta. 